\title{
TIHANYI MIKLÓS
}

\section{Közrend, közbiztonság, rendészet a keresztény közgondolkodásban ${ }^{1}$}

\begin{abstract}
A közrend, közbiztonság fogalmak körül több évtizedes vita zajlik a rendészettudomány müvelöi között. E munka keretei között arra vállalkozom, hogy a közrend, közbiztonság értékeinek keresztény közgondolkodásban való megfogalmazását vázoljam, bízva abban, hogy ezzel utat nyitok más vallások követőinek ahhoz, hogy saját vallásukban felfedezzenek hasonló értékeket. Ezért a közrend, közbiztonság fogalmi meghatározására irányuló több évtizedes szakmai és tudományos vitába egy új fogalmi rendszer megalkotásával, vagy a már meglévő meghatározások kritikai elemzésébe nem kívánok belebocsátkozni. Meghagyom ezt a rendészetelmélet kiváló mủvelőinek.

Ehelyett e vitában eddig még fel nem vetődő szempontra kívánom ráirányítani a figyelmet. Ehhez abból indulok ki, hogy a biztonság és közelebbről a társadalom belső biztonsága, a közbiztonság nem kizárólag rendészeti szempontú megközelítést igényel. Vitathatatlan azonban, hogy a rendészet, illetve a rendészettudomány egyik alapfogalmával állunk szemben. A komplex humán biztonság az embert és az emberi közösségeket fenyegető valamennyi veszélyt és ártalmat holisztikus szemlélettel vizsgálja, és ennek megfelelően igyekszik választ adni a kérdésekre. ${ }^{2}$ Maga a biztonság az egyik legelemibb emberi szükséglet. Ezért nem csupán a rendészetelmélet, illetve a hadtudomány, hanem egyebek között a pszichológia és a szociológia müvelöit is megihlette. De a társadalom és benne az egyén biztonsága felvetödött a hittudomány művelöinek körében is, illetve napjainkban is aktuális egyházi téma. A problémafelvetés indokoltságának alátámasztására elöljáróban hivatkozom a II. vatikáni zsinat Gaudium et spes kezdetủ apostoli konstitúciójára, amely a közlekedésbiztonságtól kezdve a háborúkig bezárólag külön kitér a világban jelenleg is tapasztalható biztonsági nehézségekre. A társadalmi viszonyok fejlődésével egyre szélesedik a biztonság fogalmi köre is. Míg
\end{abstract}

\footnotetext{
1 A tanulmány a KÖFOP-2.1.2-VEKOP-15-2016-00001 azonosítószámú, A jó kormányzást megalapozó közszolgálat-fejlesztés elnevezésü kiemelt projekt keretében müködtetett Egyed István posztdoktori program keretében, a Nemzeti Közszolgálati Egyetem felkérésére készült.

2 Ádám Antal: Bölcseletek, vallások, jogi alapértékek. Pécsi Tudományegyetem Állam- és Jogtudományi Kar, Pécs, 2015, 363-364. o.
} 
korábban egyértelmủ határvonal húzódott az ország belső értékeit jelentő közbiztonság és az ország területi integritását fenyegető katonai biztonság között, addig ma az aszimmetrikus hadviselés, illetve a terrorizmus következtében ez a vonal elmosódni látszik. Ugyancsak a biztonság fogalmi körét szélesíti a közbiztonság és a jogbiztonság közötti vitathatatlan összefüggés. Az utóbbi évtizedekben megjelentek olyan fogalmak, mint a magán-, az ipar-, az élelmiszer-biztonság, és még hosszan lehetne sorolni azokat a területeket, ahol a biztonság követelménye hangsúlyos szerephez jut. Természetes, hogy a globalizáció hatása a biztonság területén is érezhető, egyre komplexebb próbatételek elé állítva a hatóságokat.

Amikor az egyházak képviselői biztonságról szólnak, akkor a legtöbb esetben nem kategorizálják azt a biztonság különböző területeire, hanem komplex fogalomként kezelik. Joggal tehetik ezt, hiszen legyen szó a biztonság bármely területéről, annak középpontjában az ember, illetve az emberi élet mint védendő érték áll. Az egyházak a biztonság kérdését a humánum felöl közelítik meg, az ember biztonságáról szólnak. A keresztény emberkép nem ismer sem országhatárokat, sem jogi szabályokat, sem pedig civilizációs ártalmakat, hanem csak a megváltásra szoruló embert, aki természetéből eredően része a társadalomnak, s mint ilyen védelemre és támogatásra szorul. E megközelítést kiválóan jellemzik különböző egyházi nyilatkozatok. A Pacem in terris kezdetü apostoli konstitúció a biztonságot a lehető legkomplexebben értelmezve kiemeli, hogy a „minden népre vonatkozó közjó részéröl merülnek fel súlyos, nehéz és mielöbb megoldandó kérdések, amelyek leginkább az egész föld biztonságának és békéjének megóvására vonatkoznak”. Nemzetközi egyházi szervezetek rendre állást foglalnak a nemzetközi biztonságot fenyegető konfliktusok ügyében, egyebek között a Kelet-Ukrajna kapcsán Minszkben kialkudott és aláírt tüzszüneti egyezményről az Európai Egyházak Konferenciája (CEC) és az Egyházak Világtanácsa (WCC) is a békés rendezést sürgetô, elismerő sajtónyilatkozatot adott ki. ${ }^{3}$ Ugyancsak az Egyházak Világtanácsa kérte tagegyházait 2013-ban, hogy csatlakozzanak az Exopsed 2013 elnvezésü, korrupció elleni kampányhoz. Az egyházak nem mennek el szó nélkül a manapság egyre nagyobb és igen sokrétủ biztonsági teendőt kívánó tömeges méretü bevándorlás mellett. Ennek jegyében adott ki sajtóközleményt az Európai Egyházak Menekültügyi Bizottsága (CCME) ${ }^{4}$ Mindezek csupán illusztrációként szolgálnak azon állítás alátámasztására,

3 Yorgo Lemopoulos: Egyházi szervezetek üdvözlik az ukrajnai tűzszüneti megállapodást. Evangelikus.hu, 2015. február 16.

$4 \mathrm{http} / /$ reformatus.hu/mutat/a-biztonsagos-hataratlepesert-szolalnak-fel-az-egyhazak/ 
amely szerint az egyházak a biztonságot komplex módon, az emberi élet értékét szem előtt tartva értelmezik.

Munkámban egyebek között a rendőri feladatellátás fundamentumát jelentő közbiztonság és közrend fogalmak keresztény értelmezésére keresem a választ. Ez némiképp ellentmondani látszik az egyházak említett biztonságfelfogásának. Ez az ellentmondás azonban látszólagos, mivel a biztonság komplex megközelítése nem zárja ki annak a lehetőségét, hogy annak egyes elemeivel részleteiben foglalkozzunk.

\section{A közrend, közbiztonság, rendészet hagyományos közjogi megközelítésében fellelhető keresztény értékek}

A közrend, közbiztonság fogalmak körül kialakult vitában három megközelítési mód figyelhető meg. Az egyik természetjogi elveket vallva jogon felüli értékekből határozza meg e vitatott fogalmakat, míg a másik megközelítés markánsan pozitív közjogi alapokon áll. A harmadik szemlélet a közbiztonságot szervezési oldalról határozza meg. A két vitatott fogalom egymáshoz való viszonyában sincs egységes álláspont. Ezért a közrend, közbiztonság fogalmak értelmezése jelenleg nem megnyugtató. A rendészettudomány legismertebb képviselöi - Concha Gyözö, Szamel Lajos, Nyiri Sándor, Tauber István, Szikinger István, Finszter Géza, Balla Zoltán - által folytatott több évtizedes vita még nem zárult le. Noha a közrend, közbiztonság kifejezéseket számtalan norma - köztük több nemzetközi szerződés - alkalmazza, egységesen elfogadott, normatív, illetve tudományos fogalmat nem tudunk felmutatni. A fogalmi bizonytalanságok ellenére a rendészet és ezen belül a rendőrség feladatait legjellemzőbb módon a közrend és közbiztonság védelmével lehet összefoglalni. E rövid, elsősorban hazai szakirodalmi körkép egyetlen célja, hogy elősegítse a közrend, közbiztonság szekuláris fogalmának keresztény etikai aspektusainak, megismerését, megértését.

A német szövetségi alkotmánybíróság meghatározása szerint a közrend olyan, többnyire íratlan szabályok összessége, amelyeknek követése az uralkodó szociális és etikai felfogás szerint elengedhetetlen feltétele a rendezett társadalmi együttélésnek. ${ }^{5}$ Ez a meghatározás a jogon kívülre helyezi a köz-

5 BVerfGE 69, P. 35. Idézi Irk Ferenc: Közbiztonságtan. Főiskolai jegyzet. Rendőrtiszti Főiskola, Budapest, 2007, 70. o. 
rend fogalmát, annak tulajdonképpen erkölcsi tartalmat tulajdonítva. Ez a megoldás Finszter Géza álláspontja szerint - ha ragaszkodunk a közrend fenntartásához mint rendőrségi feladathoz - nagyfokú bizonytalanságot okoz, sőt tarthatatlan, mert feltehetően arra kötelezné az eljáró hatóságot, hogy bizonytalan etikai, erkölcsi fogalmakat emeljenek szabállyá, és ezek kikényszerítésére hatósági kényszert vegyenek igénybe. ${ }^{6}$ Részben érthető a rendészettudománynak a közrend jogon kívül helyezése miatt érzett aggodalma, hiszen ezzel a hatósági jogalkalmazás alapjai látszanak meginogni. Másfelől pedig a XX. század - és különösen a diktatúrák ideje - arra tanított meg bennünket, hogy önmagában a jognak való engedelmesség nem teremt emberi együttélésre alkalmas társadalmat. Ezért az uralkodó, általánosan elfogadott, társadalomba ágyazott erkölcsi, etikai elveket nélkülöző, vagy azokkal egyenesen szembe helyezkedö jogi rend nem képes közrendet alkotni, mert az egyén belső erkölcsi meggyőződése és a jog parancsa között feszülö ellentét zavart kelt. A zavar és a rend önmagukban is egymást kizáró állapotot jelentenek. Ennek az ambivalens társadalmi állapotnak a fenntartása folyamatosan represszív jellegü hatalmi intézkedéseket igényel. Ennek okán ilyen módon legfeljebb hosszabb-rövidebb ideig való, de a társadalom mélyén gyökeret nem eresztő társadalmi rend alakítható ki. Finszter Géza idézett munkájában tagadja az erkölcs jogalkalmazó által való joggá emelésének lehetőségét. Ezzel szemben az emberi jogoknak tulajdonít jelentőséget, elismerve azt, hogy ezek nélküli rend létezhet ugyan, de nem sokat ér. Az emberi jogok eredetére nézve több elmélet is ismeretes, köztük a természetjogi felfogás, amely szerint az emberi jogok az emberi természetnél fogva megilletik az embert. Az emberi jogok és az általuk nyújtott szabadságnak ez a természetjogi megközelítése az egyik olyan pont, ahol a keresztény értékek megjelennek a közrend, közbiztonság fogalmi rendszerében.

Concha Győző szerint a közrend alapvetően nem más, mint „az emberek közös célra való együttmüködése, melyet a jog és a természet határol”, és ez a müködés ,, a jogi és természeti határok között nem csak az állami szerveknél, de a magánosoknál is szabad"". A közrendnek három részét különbözteti meg: 1. az állami rendet; 2. a társadalmi rendet; és 3. a természeti rendet. $\mathrm{Az}$ állami renden tulajdonképpen az állami szervek müködését és szervezetrendszerét érti, de kiemeli, hogy annak nemcsak jog által meghatározott részei vannak, hanem alkotóelemei egyebek között az államcélok vagy a bíró-

6 Finszter Géza: A rendőrség joga. Nemzeti Közszolgálati Egyetem, Budapest, 2014, 34. o.

7 Concha Győző: Politika II. Grill Károly, Budapest, 1905, 308. o. 
ságok müködésének jog által nem meghatározott része is. A társadalmi rend az , az egyes magánosok tevékenységének egybefonódása és szoros egymásutánja, a gazdasági, szellemi javaknak és az ezek alapján képezödö egyéni tekintélyeknek és hatalomnak biztos eloszlása" ". Ez szoros összefüggésben értelmezendő a „köz”-ről való vélekedéssel, amelynek összetartó ereje az érdek és a felebaráti szeretet. Így a társadalmi rend lényegét tekintve az önkéntes alapú, érdekvezérelt együttmüködésen és a felebaráti szereteten nyugszik. A katolikus társadalmi tanítás szerint a közösségek, és így a társadalom is valamely célt közösen megvalósító emberek tartós összetartozása. E cél azonosítható a társadalom érdekeivel. ${ }^{9}$ A protestáns etika tanítása szerint a legerősebb társadalmi kohéziós erő a felebaráti szeretet. ${ }^{10}$ Mind a katolikus, mind pedig a protestáns társadalometika azon az elvi alapon áll, hogy miként az egyén, úgy a társadalom is Isten teremtő munkájának eredménye. Ilyen módon kimutatható a Concha-féle társadalmi rend keresztény beágyazottsága. A közrend harmadik alkotóeleme a természeti rend. Ez tulajdonképpen a természeti elemek, jelenségek rendszere, müködése, és változásai. A természeti rend többféleképpen kapcsolódik a közrendhez. Egyfelől keretet ad az állami és a társadalmi rend müködésének a megváltoztathatatlan jelenségei révén, másrészt pedig az állami és a társadalmi rend kialakulásának előfeltétele a természeti jelenségek megfékezésének képessége. Végül pedig a természeti rend felbomlása az állam és a társadalom rendjének felbomlását is előidézheti. ${ }^{11}$

A Concha-féle fogalmi megközelítés már közel visz bennünket a közrend keresztény etikai aspektusainak megismeréséhez azáltal, hogy a közrend fogalmát a természet rendje által meghatározott fogalomként írja le. A keresztény társadalomszemléletben a természet rendjében az Isten által teremtett rend jelenik meg. Az emberi társadalom pedig a természet részeként Isten teremtő munkájának eredménye, minthogy az embert alapvetően társas lénynek teremtette. Ha elfogadjuk azt, hogy ez a rend meghatározó befolyással bír az állami és a társadalmi rendre, ezáltal pedig a közrendre, akkor felismerhetjük a teremtés rendjében mindazt, ami emberi megismerés - és feltehetöen szabályozás - útján a közjogi fogalmaink szerinti közrendben ölt testet.

Mielőtt azonban a keresztény etikai nézeteket elemeznénk, vizsgáljuk meg a Concha-féle fogalom kritikáját. Finszter Géza szerint a közrend leírható erkölcsi és jogi szabályok érvényesülésének együtteseként, de meghatá-

8 Uo. 309. o.

9 Jospeh Höffner: Keresztény társadalmi tanítás. Szent István Társulat, Budapest, 2002, 33. o. 10 Sebestyén Jenő: Református etika. Iránytű Kiadó, Gödöllő, 2000, 237. o.

11 Concha Győző: i. m. 308-311. o. 
rozható kizárólag a jog alapján is. A rend jogi fogalma arra az adottságra épít, hogy az egyének és közösségeik harmonikus müködésének feltételei az ember által megismerhetők és követhetők, és e feltételek a magatartások jogi szabályozása révén megteremthetők, illetve a tilalmak által megvédelmezhetők. A jogi eszközök azonban nem alkalmasak minden társadalmi cél elérésére, ezért a jogrend a társadalmi rendnek csupán az a része, amely állami szabályozással teremthető meg. A rendészet számára a közrend egyfelől a védelem tárgya, amely felett a rendőrnek őrködnie kell, másfelől a védelem formája, amelyet a rendőrségnek és minden eljáró tagjának be kell tartania. ${ }^{12}$

Ismeretes olyan rendészeti álláspont, amely a közbiztonság és a közrend fogalma között nem tesz különbséget. Egyesek a közbiztonságot tekintik az átfogóbb kategóriának, míg mások a közrendet. A rendőrszakmai közéletben is tapasztalható a fogalmi bizonytalanság. Talán nem volt véletlen, hogy az alkotmány 2008-ig nélkülözte a közrend fogalmát. Ezzel szemben Finszter Géza a két fogalom közötti különbség fenntartása mellett foglal állást. Érvelése szerint a közbiztonság - hasonlóan a közrendhez - a rendészeti igazgatás szabályozási tárgyaként megvédendő érték, amelyet az úgynevezett negatív közigazgatás körében a jogellenes magatartásokkal szemben hatósági kényszerrel lehetséges oltalmazni. ${ }^{13}$ A közbiztonság fogalmának kétféle értelmezését különbözteti meg, normatív és a materiális megközelítés szerint. A normatív fogalmi meghatározásban abból indul ki, hogy a közbiztonság az alkotmányjog szabályozási tárgyaként államcél, amelynek megvalósítása elsődlegesen a kormányzat felelőssége. Ehhez teszi hozzá a szabadság és személyes biztonság alkotmányos jogából fakadó állami kötelezettséget. E szerint az állam a közigazgatás útján köteles gondoskodni a polgárai biztonságáról. A közbiztonság normatív fogalma egyfelől államcél, amelynek megvalósításáért a végrehajtó hatalom felelős, másfelől a jog által elismert társadalmi érték, amelynek a megvédelmezése érdekében indokolt lehet az alapvető emberi jogok korlátozása is. A nemzetközi és a hazai jog forrásai tartalmazzák azokat a konkrét törvényi tényállásokat, amelyek megvalósulása veszélyezteti a közbiztonságban testet öltő társadalmi értékeket. ${ }^{14}$

A közbiztonság materiális fogalma pedig azonos a közjog által megvédendő értékek összességével, amelyek közjogi eszközökkel való védelemre érdemesek, és ilyen módon valóban meg is óvhatók. A közbiztonság materiális

\footnotetext{
12 Finszter Géza: i. m. 35. o.

13 Uo. 38. o.

14 Uo. 45 . o.
} 
fogalma azonos azzal a közbiztonsággal, amely a hétköznapokban ténylegesen létezik és élményszerüen átélhető, vagy hiánya megszenvedhető. A közbiztonság alkotmányos demokráciákban nem lehet más, mint államcél, amelynek eléréséért szüntelenül munkálkodni kell anélkül, hogy a biztonság kikényszeríthető alanyi joggá válhatna, és abszolút beteljesülése bárki által elérhető lenne. A közbiztonság mint államcél szoros kapcsolatban van a társadalmi értékek büntetöjogi védelmével. A büntetőjogi felelösségre vonás azonban csak a jogrendet képes helyreállítani, a közbiztonságot nem. Ehhez képest a személy- és vagyonbiztonság felfogható úgy, mint egy redukált közbiztonság, ami leegyszerüsíti a bonyolult társadalmi összefüggéseket. Ez a leegyszerüsítés azért is indokolt, mert a büntetőjogi tilalmak a közérthetőségre építenek (ne ölj, ne lopj), igen jó hatásfokkal. ${ }^{15}$ Meg kell jegyezni, hogy ez a fajta leegyszerüsítés csak a személy- és vagyonbiztonságot veszélyeztető úgynevezett természetes büncselekményekre igaz. Elfogadva a közbiztonság államcélként való meghatározását, felvetődik a kérdés, hogy miként lehet megvédeni egy még meg nem valósított célkitüzést. Kiváltképp, hogy ennek a célnak az elérése soha meg nem valósulhat. Védeni - fogalmilag - csak egy már meglévő értéket lehet, vagy azokat az értékeket, amelyek egy megvalósítható célt szolgálnak.

A német szövetségi alkotmánybíróság megállapítása szerint a közbiztonság a központi javak védelmét jelenti, mint az élet, az egészség, a szabadság, a házasság, a vagyon, és az egyének javai, illetve a jogend és az állami intézmények sérthetetlensége. ${ }^{16} \mathrm{Az}$ említett központi javak közös vonása, hogy nem a jogi szabályozás emeli őket a védendő értékek sorába, hanem az emberi természet lényegnél fogva az. Azzal, hogy a modern jogrendszerek az ember alapvető jogait és ezzel a központi javakból való részesedését elismerték, e jogokat - természetjogias felfogást követve - nem konstituálják, hanem csupán deklarálják. A német természetjogias megközelítés - szemben az államcéllal - már olyan értékeket von a közbiztonság fogalmi körébe, amelyek védhetők. Ez a felfogás közel visz bennünket a közbiztonságról való keresztény etikai állásponthoz.

A közbiztonság fogalmát a magyar rendőrséget a rendszerváltás után átvilágító Team Consult cég szervezéselméleti szempontból közelítette meg. A munkájukról készült jelentés meghatározása szerint ,a közbiztonság a nem anyagi jellegü infrastruktúrának az a része, ami ahhoz szükséges, hogy az

15 Uo. 48. o.

16 BVerfGE 69, 315, 352. Idézi Irk Ferenc: i. m. 56. o. 
egyének és közösségeik megvalósithassák a társadalom számára értékes céljaikat"' ${ }^{\prime 7}$. E meglehetősen jól használható foglom egyik elemét kiemelve a közbiztonság azt a közeget jelenti, amelyben az egyén számára garantált a személyiség szabad kibontakoztatásához való jog, amellyel a társadalom érdekeit is szolgálja. A közbiztonság az egyén számára nem abszolút individualizált jogot kínál a céljai eléréséhez, hanem olyan cselekvési szabadságot ad, amellyel élve a köz javát szolgálja. Ennek megfelelően a közbiztonság az értékteremtő munkához adja meg a megfelelö társadalmi környezetet. A közbiztonság fogalmának ez a megközelítése jól korrelál azokkal a keresztény etikai tanításokkal, amelyek az egyén helyét, szerepét nem különálló individuumként, hanem a társadalom integráns részeként határozzák meg. Az Isten által teremtett ember helye az Isten által teremtett társadalomban van. ${ }^{18}$ Ebből következően a közösség értékei és érdekei nem azonosíthatók az egyes emberek értékeinek, és érdekeinek összességével, hanem ezekhez képest különböző új értékeket és érdekeket hordoz.

A rendészettudomány ismeretanyagából közel sem vonultattam fel a közbiztonság fogalmi meghatározásának teljes arzenálját. Három következtetés azonban így is körvonalazódik. Az első, hogy a rend (szándékosan nem a közrend fogalmat használtam), a rendezett társadalmi együttélés alkotja a biztonság, azon belül a közbiztonság egyik fundamentumát. Úgy tünik, hogy a rendezett együttélésnek a közbiztonság egy fokozata. A második, hogy a rendezettségnek, zavartalanságnak ezt a fokozatát a társadalmi valóság az el nem érhetö célok, vagy ha úgy tetszik, vágyak körébe számüzi. Végül pedig a közbiztonság, illetve az erre törekvés önmagában is értéket jelent, alkotmányba emelésével pedig alkotmányi értékké vált, de egyben további értékek létrehozásának feltétele is. Alkotmányi értékké nem kizárólag a közbiztonság vált, hanem a humán biztonság megannyi területe is. Ez pedig azt jelenti, hogy a biztonság alkotmánybírósági és közhatalmi védelemben részesül az alacsonyabb szintü jogi értékekkel, és az értéknek nem minősülő veszélyekkel, ártalmakkal szemben. A biztonság és egyéb jogi értékek konfliktusa esetén pedig - különös figyelemmel az elmúlt időszakban felerősödő biztonsági kihívásokra - el kell fogadnunk Ádám Antal megállapítását, amely szerint a „,nagyobb rossz elkerülése érdekében megengedhetö a kisebb rossz” észsze-

\footnotetext{
17 Bernhard Prestel: Police et management moderne. Revue internationale de Criminologie et de police technique, 2/1997., p. 134. Idézi Finszter Géza: Rendészetelmélet. Nemzeti Közszolgálati Egyetem, Budapest, 2014, 160. o.

18 A Gaudium et spes kezdetü apostoli enciklika 9. pont; Sebestyén Jenő: i. m. 237. o.
} 
rü követelményének engedve megengedhető az alacsonyabb szintü jogi értékek korábbinál erőteljesebb korlátozása. ${ }^{19}$

\section{Keresztény etikai felfogások a közrendről, közbiztonságról, rendészetről}

\section{Katolikus oldal}

A közrend, közbiztonság fogalmak gyökereit a keresztény államelméletekben kell keresnünk. Keresztény teológusok az állam eredetével és céljával hozzák összefüggésbe a rend fenntartását. Elismerik, hogy a rend fenntartását és az e feladatot ellátó szervezetet egyetlen állam sem nélkülözheti. A megoldások azonban már változatos képet mutatnak, amelyet determinál a kor, a kultúra, az állam politikai berendezkedése, társadalomszerkezete. A történelmi fejlödés egy meghatározott időszakában politikai hatalmat gyakorló egyház ugyancsak felismerte a rendfenntartás szükségességét. A középkor hol jobban, hol kevésbé rendezett társadalmi viszonyai között az állandóságot az egyház jelentette, amely politikai hatalmat is követelt magának, aminek következtében a középkori Európában kialakult az állam és egyház sajátos öszszefonódása. Már a középkorban elterjedt az a katolikus államelmélet, amely szerint az államhatalom a nép egészében testesül meg. Mivel a hatalmat a néptömeg nem képes helyesen gyakorolni, ezért azt átruházza egy vagy több személyre. A felvilágosodás kori szerződéselméletekhez képest azonban jelentős különbségek mutathatók ki. Először is az, hogy a hatalom eredete Istentől való. Ez igaz a nép hatalmára is, amelyet az uralkodóra ruház. A másik jelentős különbség abban áll, hogy a hatalom átruházása nem valamiféle önkéntes megállapodás alapján jön létre, hanem az emberi természetből eredő szükségszerüségből fakad. Az így létrejövő politikai hatalomnak a célja a közjó védelmezése. Ehhez pedig bírnia kell azzal a hatalommal, amelynél fogva képes az egyes emberek érdekeinek összességétől különböző, új értéktartalmat hordozó társadalmi rend kialakítására. Ez az egyes ember jogainak korlátozását is jelenti, amelynek célja, hogy a társadalom tagjai az őket megillető jogokat a lehető legteljesebb mértékben gyakorolhassák. ${ }^{20}$

A felvilágosodás eszméinek hatására a XIX. században megszünt az állam „keresztény” jellegének meghatározottsága, vagyis az állam és egyház viszo-

19 Ádám Antal: i. m. 273. o.

20 Joseph Höffner: i. m. 234-241. o. 
nyának az a jellemzője, amely szerint az egyház mint vallásos közösség teljes fedésben van a politikai közösséggel. ${ }^{21}$ E szekuláris folyamat ellen $X V I$. Gergely pápa szólt elöször a Mirari vos arbitramur kezdetü enciklikájában, amelyben teljes egészében megmutatkozik a régi rend iránti elkötelezettsége. Az ő felfogásában a földi uralkodók hatalmának szilárdsága az egyház javát szolgálja, hogy az teljesíthesse a küldetését. Ezért azon kell munkálkodni, hogy az államokban rend és békesség legyen. A XIX. századi forradalmakra adott katolikus válasz az volt, hogy a hagyományos rendet meg kell erősíteni, és hogy a változásokon csak egy megerősített és az állam által is támogatott államegyház tud hatékonyan úrrá lenni. ${ }^{22}$ Szintén a liberalizmus ellen fejti ki a katolikus egyház tanítását XIII. Leó pápa az Immortale Dei kezdetü apostoli enciklikájában. Ebben megerősíti, hogy minden hatalom - ideértve a világi hatalmat is - Istentől való. Később pedig úgy fogalmaz, hogy a nép uralkodási joga olyan felfogásának, amely szerint ez a jog az Istenre tekintet nélkül, természettől fogva megvan a népben, nincs elég ereje a közbiztonság, a rend és nyugalom fönntartására. ${ }^{23} \mathrm{Az}$ Au milieu des sollicitudes kezdetü enciklika szerint ez a hatalom mindig változhatatlan és tiszteletre méltó marad, hiszen a természeténél fogva azért alapíttatott, hogy a nélkülözhetetlen közjóról gondosodjék, ami egyben az állam legfőbb célja. A változhatatlanság nem az államformára, hanem csak az állam céljára igaz. Bármelyik államforma megfelelő lehet, ha a társadalom saját céljára, vagyis a közjó megvalósítására irányul, mivel a társadalomban a hatalmat ennek megóvása érdekében hozták létre. Az enciklika elismeri, hogy a közrend megköveteli egy kormány létét, hiszen a törvényes rendhez szükség van a hatalomra. Ezzel szemben a lázadás - amelynek oka a féktelen szabadság, hangsúlyosan beleértve a vallás és a sajtó szabadságát - gyülöletet szít a polgárok között, polgárháborút okoz, és visszaveti a nemzeteket az anarchia káoszába. Az állam iránti tisztelet és függőség mindaddig fennmarad, míg a közjó ezt megkívánja, hiszen a közjó meglétének garantálása az államban a legfontosabb törvény Isten tisztelete után. ${ }^{24}$

\footnotetext{
21 José Casanova: Public Religions in the Modern World. Chicago-London, 1994

22 Gajer László: XIII. Leó pápa megnyilatkozásainak filozófiatörténeti előzményei. Különös tekintettel a vallásszabadságra. Doktori disszertáció. Pázmány Péter Katolikus Egyetem Hittudományi Kar, Budapest, 2013

23 E pápai enciklika szól a vallásszabadság ellen, amely lényegét tekintve istentagadásra vezet, felemeli hangját a sajtószabadság ellen, amelyből sok rossz és gonosz dolog fakad. Lényegét tekintve e pápai enciklika egy autoriter, az állam és a katolikus egyház korábbi viszonyának helyreállításával kialakított állammodellt állít elénk.

24 Gajer László: i. m. 174. o.
} 
Az idézett enciklikák olvasatában a közjó egyfelöl a társadalmi javakból történö részesedést jelenteti, másfelöl pedig magában hordozza a társadalom müködésének alapjait jelentö belsö békét is mint a javak megteremtésének feltételét. Sajátos katolikus álláspontot mutat, hogy ennek alapjaként az enciklikát jegyző pápa az állam és egyház helyes együttmüködését látta. Ez azt jelentette, hogy az állam és egyház elválasztása fel sem vetődött, mert ez azt jelentette volna, hogy az emberi és az isteni törvényhozást is el kellene választani egymástól. Ezzel pedig az enciklika - mára meghaladottá vált - érvelése szerint az állt volna elö, hogy állam nem tudja az emberi jogokat garantálni, amelyek pedig éppen az ember Isten iránti kötelezettségeiből fakadnak. Az állam közjó megteremtése iránti müködése arra is való, hogy polgárait - az egyház szolgálatát támogatva, polgárait Isten iránti kötelezettségeik teljesítésében segítve - az üdvösségre vezesse.

Mindezek alapján az látszik kibontakozni, hogy a II. vatikáni zsinatig a közjó és az annak részét jelentö közrend egymásra épülö fogalmai szoros öszszefüggést mutatnak az állam és egyház elválaszthatatlanságával. Ennek alapja, hogy az egyház önmagát az állam legerősebb támaszának tartotta, vagyis ha az állam az elválasztás mellett dönt, akkor lemond legerősebb támaszáról. Ezzel pedig elveszíti azt a képességét, hogy a közjót szolgálja. ${ }^{25} \mathrm{~A}$ közjó definícióját először XXIII. János pápa adta meg a következőképpen: „az államok vezetöinek világosan tisztázniuk kell a közjó helyes fogalmát, ami magában foglalja a társadalmi élet azon feltételeinek az összességét, melyek révén az egyének teljesebben és akadálytalanabbul képesek tökéletesedésük felé haladni" ${ }^{\prime 26}$. Mindenki felelös a közjóért, és megvan az a joga is, hogy a közjó keresése nyomán kialakuló társadalmi életkörülmények haszonélvezője legyen. Ha a közjó magában hordozza a társadalmi békét - annak külső és belső dimenzióját egyaránt -, akkor el kell jutnunk oda, hogy legalábbis a belső béke lényegében társadalmi össztermék, éppen úgy, mint ahogyan a közbiztonság is az. Ennek felismeréséhez el kell fogadni, hogy a közbiztonság megteremtése nem rendészeti feladat, az csupán széles körü társadalmi együttmüködéssel valósítható meg. ${ }^{27}$

Az ember természetes életközege a közösség, ennek következtében az egyén javai szükségképpen kapcsolatban állnak a közjóval. A közjó alapelve valamennyi személy méltóságából, egyszeri voltából és egyenlőségéből ered,

\footnotetext{
25 Uo. 173 . o.

26 XXIII. János pápa Mater et Magistra kezdetủ enciklikája.

27 Major Róbert: Rendészet, közlekedésrendészet. In: Barabás A. Tünde (szerk.): Tanulmányok Irk Ferenc professzor 70. születésnapjára. Országos Kriminológiai Intézet, Budapest, 2012, 192. o.
} 
figyelembe véve, hogy az egyén a közösség része. Ennek alapján fogalmazza meg a II. vatikáni zsinat Gaudium et spes kezdetü enciklikája, hogy „a közjó napjainkban egyre egyetemesebbé válik, és az egész emberi nemet érintö jogokat és kötelességeket foglal magában. Minden csoportnak számot kell vetnie a többi csoport szükségleteivel és jogos igényeivel, söt az egész emberi család közjavával is. " ${ }^{28}$ A közjó érdekében tehát törekedni kell azoknak a társadalmi feltételeknek az összességére, amelyek mind a csoportoknak, mind az egyes tagoknak lehetővé teszik, hogy teljesebben elérjék tökéletességüket. A közjó nem azonos a társadalom tagjait megillető részleges javak összességével. Mivel a közjó mindenkié együtt és külön-külön is, ezért közös dolog lévén oszthatatlan; csak együtt érhető el, növelhetö, örizhető a jövő számára is.

A társadalmi cselekvés a közjó megvalósításában válik érzékelhetővé. Következésképpen a közjó az erkölcsi jó társadalmi, közösségi dimenziójaként fogható fel. A közjó három lényeges elemet foglal magában. Először a személy tiszteletét. Így ír erröl a Gaudium et spes kezdetü enciklika: „A közjó nevében a közhatalomnak tiszteletben kell tartani az emberi személy alapvetö jogait. Az ember számára tehát hozzáférhetôvé kell tenni mindazt, ami a valóban emberi élethez szükséges: ilyenek a táplálék, a ruházat, a lakás; jog az életállapot szabad megválasztáshoz és a családalapitáshoz, neveltetéshez, munkához, jó hirnévhez, tisztelethez, megfelelö tájékoztatáshoz, a saját helyes lelkiismeret szerinti cselekvéshez, a magánélete védeleméhez és a jogos szabadsághoz, mely magában foglalja a vallásszabadságot is. ${ }^{~} 29$ Másodszor: a közjó megköveteli a helyes társadalmi rendet és a szervezetek kibontakozását. Ez az állam felelőssége. És végül: a közjó magában foglalja a békét, vagyis az igazságos rend állandóságát és a biztonságot. Feltételezi, hogy a hatalom gondoskodik - tisztességes eszközökkel - mind a társadalom, mind tagjainak biztonságáról. Ezen alapul a jogos ön- és közösségvédelem. ${ }^{30} \mathrm{E}$ megközelítésben a közjó fogalma magában foglalja a szekularizált közbiztonság-fogalom egyes elemeit.

A közjó tartalmáról a Hittani Kongregáció 2003. január 16-án kelt dokumentuma így ír: „E közjó magába foglalja az olyan javak támogatását és védelmét, mint a közrend, a béke, a szabadság, az egyenlöség, az emberi élet tisztelete, a környezetvédelem, az igazságosság, a szolidaritás, stb. ${ }^{{ }_{3} l}$ A katoli-

\footnotetext{
28 A II. vatikáni zsinat Gaudium et spes kezdetü apostoli konstitúciója I. rész 2. fejezet 26. pont. 29 Uo.

30 Farkas Péter: A katolikus egyház társadalmi tanításának alapelvei és gyakorlati alkalmazásuk. Kötelékek, 2012/2.

31 http://uj.katolikus.hu/konyvtar.php?h=147\#JB10
} 
kus álláspont a közjóról egy olyan átfogó érték képét vetíti elénk, amely ahhoz szükséges, hogy az egyén szabadságjogai révén teljes értékü - és tegyük hozzá Krisztushoz vezető - életet élhessen, illetve meglegyen az a képessége, hogy a társadalom javát és végső soron üdvösségét szolgálhassa, vagyis megvalósíthassa a társadalom számára hasznos céljait. Ebben a megközelitésben egyfajta vallásos közbiztonság-fogalom rajzolódik ki, amelyben a közrend és (köz)biztonság a közjó részeként az ember boldogulását elösegítő társadalmi állapot egyik feltétele.

A közjó eléréséhez szükséges emberi tevékenység pedig ekképpen fogalmazható meg: „Ebböl következően az emberi tevékenység alapszabálya ez: Isten terve és akarata szerint legyen összhangban az emberi nem igazi javával, s az embernek mint egyénnek és a társadalom tagjának tegye lehetövé teljes hivatásának szolgálatát és betöltését. "32 Mint láttuk, a közjó szolgálata mindenkinek kötelessége. Az államnak ehhez arról kell gondoskodnia, hogy mindenki megtalálja saját hivatását, amelynek területén munkálkodva képes eleget tenni a közjó megteremtésével kapcsolatos kötelezettségének. Ha ez a terület a közrend, közbiztonság fenntartása, akkor ez nemhogy nem ellentétes a katolikus hit társadalmi tanításával, hanem kifejezetten megbecsülésre méltó. Csupán arra kell törekedniük, hogy hivatásuk gyakorlásakor képesek legyenek földi tevékenységüket úgy irányítani, hogy „,az emberi, családi, szakmabeli, tudományos és technikai törekvéseiket élö szintézisbe fogják a vallási értékekkel, s ezek rendezö ereje mindent Isten dicsöségére fordit" ${ }^{33}$.

\section{Protestáns nézöpont}

A reformáció az egyház megújítását, Krisztushoz való visszavezetését tűzte ki célul. Hamar túllépett azonban a szük értelemben vett vallási kereteken, és szükségessé vált, hogy a reformátorok politikai és társadalmi kérdésekben is - teológiai alapokon - állást foglaljanak. A rend és biztonság mint értékek korán megjelentek a protestáns etikában. Ez szoros összefüggésben áll a reformáció kezdeti időszakát jellemző társadalmi állapotokkal. Már Luther Márton müködésének kezdetén kirobbant az a német parasztlázadás, amelylyel szemben a reformátor is felemelte szavát. A vallási szembenállás ez után is létükben fenyegette az eltérő vallásúakat; katolikus fejedelemségekben a protestánsokat, protestáns fejedelemségekben pedig a katolikusokat. Később

32 Gaudium et spes, I. rész 3. fejezet 35. pont

33 Gaudium et spes, I. rész 4. fejezet 43. pont 
pedig a vallásháborúk nyomták rá bélyegüket Európa történelmére. Érthető, ha a reformátorok számára korán fontossá vált az állam belső és külső békéje egyaránt. Mind Luther, mind pedig Kálvin János nagy súlyt fektetett az állam és az egyház kapcsolatára, illetve az állam ez idő tájt leghangsúlyosabb funkcióját jelentő védelemre. Ezt figyelembe véve most a hatalomgyakorlás egyetlen területét érintem, mégpedig a belső rend fenntartásának funkcióját. Luther, Krisztus szavait idézve kezd a fejedelmi hatalomgyakorlás módjának ismertetésébe. E szerint „A világi fejedelmek uralkodnak és akik fejedelmek, eröszakkal dolgoznak" ${ }^{34}$. Mindazonáltal hangsúlyozza, hogy a fegyver, az erőszak csak legutolsó eszköz, amelyet megelőz a törvény, a józan ész, és mindenekelőtt az Istenre figyelés. A törvény és a józan ész kapcsolatáról elmondja, hogy valamennyi törvénynek egyetlen közös vonása van, mégpedig az, hogy szükség ellen nem kényszerít. Visszautalva arra a gondolatra, amely szerint az erkölcsi renddel ellentétes törvény nem képes közrendet alkotni, ezt kiegészíteném azzal, hogy a józan ésszel ellentétes törvény hasonlóképp kudarcra van ítélve a közrend dolgában. Mindennél jobban látni ezt akkor, ha megnézzük, hozott-e bármilyen eredményt a hajléktalanság, a munkanélküliség vagy a szegénység rendészeti szempontú kezelése. Luther keresztény módon való uralkodásról vallott felfogása szerint a kormányzás szolgálatot jelent, mégpedig a nép, ha úgy tetszik, a „köz” szolgálatát. Elfogadja az uralkodó jogát a büntetés kiszabására, vagy akár egy háború megindítására. Elfogadja, hogy ez az egyesek érdekeit sértheti, ezért mondja, hogy az uralkodó csak a nép érdekében alkalmazhat eröszakot, minthogy a népet védelmeznie és segítenie kell. A nép megvédése ebben az értelemben a külső ellenségtől és a belső jogsértésektől való megvédést is jelenti. ${ }^{35}$ Mai szóhasználattal élve a keresztény uralkodó sem mondhat le a rendészeti és honvédelmi funkciók ellátásáról.

Amikor Luther a rend fenntartására hivatottakról szól, akkor Keresztelő János tanításából indul ki. E szerint amikor római katonák kérdezték meg tőle, hogy ők mit tegyenek azért, hogy üdvözülhessenek, így válaszolt nekik: ,,Senkit ne bántsatok, se meg ne zsaroljatok, hanem elégedjetek meg zsoldotokkal "., E kérdéskör bővebb elemzése már átvezetne bennünket a rendészeti etika területére, ezért csak nagyon röviden két következtetést kell levonnunk Luther nyomán. Az egyik az, hogy a fegyveres hatalmat Isten rendelésének tartja, máskülönben Keresztelő János azt mondta volna, hogy többé ne legyenek katonák. Ez

\footnotetext{
34 Idézi Luther Márton: A világi felsőségről, hogy meddig tartozik neki az ember engedelmességgel. In: Masznyik Endre: D. Luther Márton egyházreformáló iratai. II. kötet. Pozsony, 1906, 399. o. 35 Uo. 399-410. o.
} 
előre vetíti annak képét, hogy az állami szolgálat és azon belül a fegyveres szolgálat nemhogy összeegyeztethetetlen volna a keresztény hittel, de Isten szolgálatának egy nevesített és elismerésre méltó területe. A másik következtetés pedig az, hogy ez a hatalom Luther megfogalmazásában a rosszak büntetésére, és az istenfélők védelmére van. A háborgatást elszenvedőket megilleti ugyan a jogos védelem - amellyel élni nem mindenki és nem minden esetben képes, ezért csak kivételes lehetőség -, de a megtorlás már nem. ${ }^{37}$ Ezt összevetve Luther kétbirodalom-elméletével, illetve azzal az intelemmel, hogy a keresztény emberek olyan életmódot folytassanak, hogy ne legyen szükségük a világi hatalomra, láthatóvá válik, hogy az istenfélőkről eleve feltételezi a - világi és isteni - törvények betartását. Ezért e helyütt Luther a békés, jogkövetö társadalom védelmét fogalmazza meg szolgálatként. Erröl a védelemröl a fejedelemnek kell gondoskodnia mindazokkal szemben, akik másokat háborgatnak. A „köz” rendjének védelme a Luther tanításain nyugvó protestáns etika számára tehát az állam centrális feladata, ebben részt venni Isten szolgálatát jelenti. Sőt, e szolgálat kifejezetten hasznos és szükséges, mi több, felemelő.

Az eddigiek alapján ez az állami szerepvállalás legalább négy funkciót jelent: a honvédelemre jellemző külső védelem, a mai kor rendészetére jellemző védelem és beavatkozás, az igazságszolgáltatás, végül pedig a büntetésvégrehajtás, amely ma szintén a rendészet körébe tartozó állami feladat. Maga Luther ezt így foglalja össze: „,Mivel pedig a hatóság nagyon szükséges és hasznos az egész világra nézve, hogy a béke fenntartható, a bün büntethetö, s a gonoszok akadályozhatók legyenek. ${ }^{38}$ Ezzel pedig magyarázatát adja annak, hogy a ,"ne állj ellen a gonosznak" krisztusi parancsolat miért engedi meg a gonosztevők elleni fegyveres állami szolgálatot. Arra ugyanis a keresztény ember nem a maga érdekében, hanem mások szolgálatára és mások szükségére vállalkozik. Maga személyére nézve a gonoszt eltürni, mások személyére nézve pedig büntetni tartozik. ${ }^{39}$ Ebben nagyon fontos üzenet rejlik a mai rendészet számára is, mégpedig az öncélúság tilalma. Az állami hatalom birtoklása egyben felelősséget jelent a társadalom irányába. A közösség nem azért ruházta fel a rendőrt a legitim fizikai erőszak és a legitim jogkorlátozás hatalmával, hogy ezt a hatalmat a maga javára gyakorolja.

Természetes, hogy Luthernél a „rendészeti hatalom” Isten felhatalmazásából ered, miként Ö minden hatalom forrása. Azzal együtt, hogy ez a tétel nem illeszthető bele szekularizált jogrendszerünkbe - teológiai igazságtartalmát

36 Lukács evangéliuma 3,14. Idézi Luther Márton: i. m. 367. o.

37 Luther Márton: i. m. 367. o.

38 Uo. 374. o. 
azonban nem kérdőjelezem meg -, úgy vélem a Luther által megfogalmazottak ma is iránymutatók lehetnek a rendészeti hatalomgyakorlás számára.

Kálvin államszervezési teljesítménye a genfi alkotmányban bontakozott ki. Nem véletlen, hogy korának kiemelkedő jogászai között tartjuk számon. Munkássága idején választ keresett az államhatalom funkcióira is. Ennek keretében vázolta, hogy az állam egyfelől köteles a polgárairól gondoskodni (ma úgy mondanánk, közszolgáltatásokkal ellátni), másfelől pedig köteles a köz nyugalmát, a közállapotok zavartalanságát szavatolni (védelmi funkció), végül pedig köteles a hitet megvédeni. Ö maga így ír erröl: „Ennek a kormányzásnak nemcsak az a teendöje - ami az itt emlitett dolgok haszna -, hogy az emberek lélegezni, enni, inni és melegedni tudjanak [...] De nem csak ez a gondja, hanem az is, hogy a bálványimádás [...] fel ne üsse a fejét és el ne terjedhessen a nép között. Vigyáz arra, hogy a köznyugalmat senki meg ne zavarhassa, és mindenki épen és sértetlenül megtartassa azt, ami az övé, és hogy az emberek zavartalanul érintkezhessenek egymással, és hogy a becsület és a mértéktartás megöriztessék. "º Mondhatnánk, hogy a hit védelmét mára felváltotta a plurális vallásszabadság garantálása.

Kálvin nem beszélt pluralizmusról, de az addigi történelem során elöször fogalmazta meg a vallásszabadság gondolatát. Így vált a vallásszabadság az első szabadságjoggá. Ebből a szempontból nézve Kálvin a hit védelmében a hit szabadságának védelmét is látta. Ezzel - igaz, kezdetleges módon - először került sor az állam alapjogvédelmi kötelezettségének megfogalmazására. A kép teljességéhez hozzátartozik az is, hogy épp Kálvin volt az, aki elöször fogalmazta meg és juttatta következetes szigorral érvényre az állam és egyház elválasztását. Az állam védelmi funkcióját roppant széles körben látta érvényesíthetőnek. Kiterjesztette az erkölcsre, a nyugalomra és - számunkra lényeges módon - mindenki közös biztonságára és békéjére.

A világi - vagy ahogyan Kálvin fogalmaz, polgári - hatalom gyakorlását nem csupán kívánatosnak, hanem különleges szentségnek, az összes hivatás közül leginkább tiszteletre méltónak nevezte. Ennek oka, hogy a hatalom hordozói Isten nevében gyakorolják a rájuk bízott hatalmat. Kálvin nézetei szerint a polgári kormányzat rendészeti legitimációs forrása - mint ahogyan minden más hatalom forrása is - Istentől ered. Álláspontja szerint ez különleges felelősséget követel azoktól, akikre e hatalom bízatott. Jogállami demokráciánk fogalmai szerint ez a felelősség nem jogi, hanem sokkal inkább erkölcsi felelősséget jelent. Kálvin korában is hasonló jelentéssel bírt. A hívő

39 Uo. 374-376. o.

40 Kálvin János: Institutio. Tanítás a keresztyén vallásra. Kálvin Kiadó, Budapest, 1991, 288. o. 
ember számára - teológiai értelemben - nincs is szükség jogi felelösségre, mert mint ahogyan Luther fogalmaz: „, Az igaz ember mindent és jobban tesz, mint ahogyan azt a törvény megköveteli." "4t A fegyveres hatalom egyaránt megtestesíti Kálvinnál a rendészeti és a katonai hatalmat, lévén hogy e korban nem beszélhetünk önálló rendészetről. Ezért a fegyveres hatalom célját mindkét területen megvalósítandó módon abban látja, hogy az uralkodó gondoskodjon országa nyugalmáról, fellépjen az erőszakot tevők ellen, és végül büntesse a gonosz tetteket. E téren ugyanazokat a funkciókat határozza meg, mint Luther. Csakhogy Kálvin a továbbiakban kifejezetten hivatkozik a törvényes rendre, amelynek megbontása a polgári hatalom részéről szükségszerủen vezet a fegyveres erő alkalmazásához a rend helyreállítása érdekében. ${ }^{42}$ A törvényes rendet a közösség rendezett müködéséhez szükséges alapként határozza meg, ezzel elismerve azt, hogy ahol nincs törvényen nyugvó rend, ott sem az államélet, sem az egyén élete, sem pedig a hit gyakorlása nincs biztonságban. Ezzel pedig eljutunk oda, amit ma a közrend és közbiztonság fogalmakkal jelölünk. Hasonló elvi alapokról kiindulva Szathmáry Béla egyenesen úgy fogalmaz, hogy ,„ez [tudniillik a jó cselekedetek megvédése és a rossz elleni fellépés - a szerzö megj.] a mai fogalmaink szerint a közjó és a közrend biztositását szolgálja, amelyre Kálvin szerint azért van szükség, mert a Krisztusban kapott szabadságunk embertársaink irányában nem korlátlan, $s$ nem feledkezhetünk meg e korlátok megtartásáról ". ${ }^{33}$

Kálvin az erőszak alkalmazásával kapcsolatban hasonlóképpen érvel, mint Luther. Kifejti, hogy az emberölés a Biblia tanítása szerint tilos, de ez a parancsolat arra való, hogy ne maradjon büntetlenül a gyilkosság. Amikor pedig az Isten szolgálatában állók fegyvert fognak a gyilkos ellen, akkor Isten parancsolatát hajtják végre. Ennek kapcsán megjegyzi Kálvin, hogy a hatalomnak két véglettől kell tartózkodnia, a túlzott szigortól, mert ezzel inkább sebez, semmint gyógyít, és a túlzott engedékenységtől, mert ezzel pedig az ártatlanok sokaságának pusztulását okozza. ${ }^{44}$ Ezzel a kor keretei között kijelöli az erőszak alkalmazásának arányosságát. Nem jogi, hanem inkább erkölcsi mércét állít. Ha a halálbüntetés és kínvallatás alkalmazható módjai alapján elképzeljük a korszak kegyetlenségét, nem is várhatunk reálisan jogi arányossági mércét.

\footnotetext{
41 Luther Márton: i. m. 372. o.

42 Kálvin János: i. m. 294. o.

43 Szathmáry Béla: Kálvin és a kálvinizmus aktualitása a világban és az egyházban. Napút, 2009/9. http://www.napkut.hu/naput_2009/2009_09/071.htm

44 Kálvin János: i. m. 295. o.
} 
Mindezek alapján a protestáns etika álláspontját követve a következő konzekvenciák adódnak. Az állam Isten rendelése alapján jött létre, és Isten felhatalmazása alapján gyakorolja a hatalmat, mégpedig a bünösök megfékezésére. ${ }^{45} \mathrm{E}$ helyütt nem a teológiai értelemben vett bünről van szó amely tetteken kívül elkövethetö szóban, vagy gondolatban is -, hanem arról a bünröl, amelyet emberi törvény is bünné tett, hogy büntetése révén a köz nyugalma megmaradjon. A világi hatalom és a világi törvény elsődleges célja az emberi gonoszság megfékezése. Ehhez nélkülözhetetlenül szükséges az állam mint szuverén hatalom jogalkotói hatalmának elismerése. ${ }^{46}$ Protestáns alapokon állva az látszik, hogy az állam legalapvetőbb, ha tetszik legősibb rendeltetése, tulajdonképpen az állam létrejöttének közvetlen oka a rend, közelebbről pedig a közrend, illetve az állam külső rendjének védelme. Abraham Kuyper is elismeri azt a kálvini igazságot, hogy bün nélkül nem volna szükség sem hatóságra, sem törvényre. Álláspontja szerint azonban ez természetellenes állapota az embernek, mert az ember természetéből fakadóan (a kifejezés arisztotelészi értelmében) társas lény, tehát nem önmagában, hanem emberi közösség részeként létezik, ennélfogva ennek a közösségi létnek a szervezésére bün nélkül is szükség volna felsőségre. ${ }^{47} \mathrm{E}$ megközelítés némiképp egybecseng a katolikus állásponttal, amely szerint a természeténél fogva társadalmat alkotó emberi közösségben a közjó megteremtése az állam létének célja és oka. Meglehet Kuyper érvelése zárt logikai rendszert alkot, annak helyességét nem lehet megállapítani, minthogy nem tekinthetünk úgy a társadalmakra, mintha azokban bün nem volna. A bün tényétől elvonatkoztatni senki, valójában még Kuyper sem tud, ezért továbbra is tartom magam ahhoz a Luther és Kálvin tanításain alapuló nézethez, amely szerint az állam létrejöttének elsődleges célja a társadalom belső és külső békéjének, vagy a közrendnek és a külső biztonságnak a megteremtése.

\section{Összegzés}

Egyfajta sommás összegzés ez lehetne: „Nincs semmi új a nap alatt.”48 A közbiztonság és közrend szekuláris fogalmai több ponton korrelálnak a keresz-

\footnotetext{
45 Mark J. Larson: Calvin’s doctrine of state. Eugene, 2009. Ugyanakkor a szerző azon álláspontja, amellyel párhuzamot von szent háború és napjaink háborúi, valamint a totális háború között, erősen vitatható. 46 William A. Mueller: Church and State in Luther and Calvin. Nashville, 1954 47 Abraham Kuyper: Lectures on calvinism. Six Stone-lectures. Princeton, 1898, p. 79. 48 Prédikátor könyve 1,9
} 
tény társadalometika hasonló tartalmú értékeivel. Ilyen közös pontként lehet megemlíteni az egyén és a közösség viszonyát, ebben az egyén felelősségét; a rendet, illetve a rendezettséget mint a társadalmi együttélés alapjait; a biztonság és védelem legmagasabb fokának célként való meghatározását; az állami szerepvállalás fontosságát. Természetes, hogy a vallásilag determinált és a szekularizált fogalmak nem feleltethetők meg minden tekintetben egymásnak. Ilyen különbözőségként lehet meghatározni a rend forrását, amely a keresztény etikában az Isten teremtő munkája, a szekuláris felfogás szerint a társadalmi rend, illetve az állami jogalkotás. Ezzel kapcsolatban megemlíthető, hogy a protestáns etika álláspontja szerint földi viszonylatok között a rend államilag szabályozott törvényes rendben ölt tényleges módon testet. Ez szavatolja a rendezett együttélést. A különböző keresztény felekezetek társadalmi tanításaiban fellelhető különbözőségek hangsúlyozása helyett az azonosságok előtérbe helyezésével a következő főbb konzekvenciák adódnak. A keresztény társadalometika számára az egyén mint a Teremtő egyedi alkotása nem pusztán individuum, hanem élete, léte szorosan hozzákötődik a társadalomhoz. Miként egy test tagjai, úgy kapcsolódnak össze az egyének és válnak eggyé, egy közösséggé. Ez a közösségi lét feltételezi az egymásrautaltságot és a másikért való felelősséget. Az ,, amint szeretnétek, hogy az emberek veletek bánjanak, ti is úgy bánjatok velük!" parancsolat az egyén érdekeinek sérelme nélküli, harmóniára törekvő társadalom képét vetíti elénk. ${ }^{49}$ Minthogy mindig vannak olyanok, akik e parancsolatot megtartani képtelenek, az ideális viszonyokat mutató társadalom képe minden esetben tökéletlen lesz. E viszonyok között is szükséges azonban a rend fenntartása, mert e nélkül bármiféle társadalmi élet elképzelhetetlen.

\section{IRODALOM}

Ádám Antal: Bölcseletek, vallások, jogi alapértékek. Pécsi Tudományegyetem Állam- és Jogtudományi Kar, Pécs, 2015

Casanova, José: Public Religions in the Modern World. Chicago-London, 1994

Concha Győző: Politika II. Grill Károly, Budapest, 1905

Farkas Péter: A katolikus egyház társadalmi tanításának alapelvei és gyakorlati alkalmazásuk. Kötelékek, 2012/2.

Finszter Géza: A rendőrség joga. Nemzeti Közszolgálati Egyetem, Budapest, 2014

49 Lukács evangéliuma 6,33 
Gajer László: XIII. Leó pápa megnyilatkozásainak filozófiatörténeti előzményei. Különös tekintettel a vallásszabadságra. Doktori disszertáció. Pázmány Péter Katolikus Egyetem Hittudományi Kar, Budapest, 2013

Höffner, Jospeh: Keresztény társadalmi tanítás. Szent István Társulat, Budapest, 2002

Kálvin János: Institutio. Tanítás a keresztyén vallásra. Kálvin Kiadó, Budapest, 1991

Kuyper, Abraham: Lectures on calvinism. Six Stone-lectures. Princeton, 1898

Larson, Mark J.: Calvin's doctrine of state. Eugene, 2009

Lemopoulos, Yorgo: Egyházi szervezetek üdvözlik az ukrajnai tüzszüneti megállapodást. Evangelikus.hu, 2015. február 16.

Major Róbert: Rendészet, közlekedésrendészet. In: Barabás A. Tünde (szerk.): Tanulmányok Irk Ferenc professzor 70. születésnapjára. Országos Kriminológiai Intézet, Budapest, 2012, 192. o.

Mueller, William A.: Church and State in Luther and Calvin. Nashville, 1954

Prestel, Bernhard: Police et management moderne. Revue internationale de Criminologie et de police technique2/1997.

Sebestyén Jenő: Református etika. Iránytü Kiadó, Gödöllő, 2000

Szathmáry Béla: Kálvin és a kálvinizmus aktualitása a világban és az egyházban. Napút, 2009/9. http://www.napkut.hu/naput_2009/2009_09/071.htm 